\title{
Sabbath keeping and Sunday observance as spiritual practice ${ }^{1}$
}

\author{
Pieter G.R. de Villiers \\ University of the Free State \\ Bloemfontein, South Africa \\ pgdevilliers@gmail.com \\ George Marchinkowski \\ University of the Free State \\ george@swuc.co.za
}

\begin{abstract}
This article investigates recent interest in the spiritual practice of Sabbath keeping in the light of its history in Judaism and Christianity. It will focus, firstly, on the spiritual nature of Sabbath keeping in Biblical texts and its reception in Judeo-Christian traditions. It will spell out comprehensive, multifaceted approaches to Sabbath keeping and Sunday observance in these traditions and how dynamically these approaches were developed in terms of later contexts. The article will then analyse the positive impact of this spiritual practice on human relationships, but more importantly, its role in creating awareness of the divine presence which represents its most essential dimension. This will reveal how transformative Sabbath keeping as a spiritual practice can be in the spiritual journey, even and also in contemporary contexts. The aim of the article is to investigate insights that spirituality authors can gain from past history in order to meaningfully respond to challenges in their own context and to empower them to counter the serious consequences for the spiritual health of those who are victims of a consumerist culture. The article is by necessity merely an overview, without in-depth discussion of the detail of Sabbath in various historical phases. Important is a general trend that reflects the ebb and flow of Sabbath keeping in the course of history, its tenacity as a spiritual practice and its deeper meaning in the life of faith communities.
\end{abstract}

1 In this article, Sabbath keeping as spiritual practice is discussed to include and refer to Sunday observance as well. Sunday observance is a more focused term, characteristic of a Christian context. Though there are indeed differences between Sabbath and Sunday observance, Sunday observance, by necessity shares commonalities with Sabbath keeping because of its roots in Hebrew Scriptures. For practical reasons, the two terms will be used interchangeably in this article. 


\section{Keywords}

Spirituality; spiritual practices; Sabbath keeping; Sunday observance; Sabbatarianism

\section{Introduction}

Faith communities have always placed a high premium on keeping the Sabbath as a day of rest. For a long time, they could also count on the support of the State to legislate activities that promoted keeping the Sabbath. This formidable partnership in countries with a strong presence of churches, affected cultural, social, commercial and sport activities in a major way. With the waning of Church authority and growing secularisation, the situation changed drastically. For some, though, Sunday observance itself also contributed to its own demise because of its legalistic, formalistic nature that made it a deadening, boring experience. Sabbath keeping in many cases became mostly a matter of attending worship services. The consumer and entertainment culture affected Sunday observance to such an extent that Sundays looked like any other day of the week. ${ }^{2}$

However, the hasty and hectic lifestyle that came about as collateral damage of consumerism, has taken its toll and intensified the pressures of an already busy lifestyle. The overwhelming demands of the workplace encroached on people's lives by pressurising them to work long hours, including on Sundays. The entertainment industry not only served consumerism, but often offered more attractive offerings than the religious institutions could do. This affected Sabbath keeping as well. Mental health became a major concern as people were overwhelmed by a restless lifestyle without breakaways facilitated by traditional Sabbath keeping that succour and refresh. Sunday observance, previously offering a necessary and reinvigorating change of rhythm, was shifted to the fringes of the social discourse as the preoccupation of the few. All this meant that it lost much of its spiritual character and meaning, even within faith communities.

Significantly, though, this new situation eventually led to reconsidering the classical spiritual practice of Sabbath keeping. Recent research on the Sabbath in Scripture, Jewish and early Christian communities, and in the

2 Cf. the characterization of work in contemporary settings by Bass (2015:31-5). 
history of the church offered some new insights and trends that revealed how central this practice has been in the religious discourse and how its very nature as spiritual practice may counter the harsh effects of consumerism and performance pressure in contemporary driven societies. It suggested the healing potential of this practice for those who suffer under the burden and exploitation of a modern (or contemporary), materialist lifestyle.

This research is especially helpful in its analysis of Sabbath keeping as a complex and multifaceted phenomenon, confirming its dynamic nature and its ability to enrich the spiritual life in very different contexts. Such research illuminates why and how Sunday observance was held in high regard, why it has the potential to overcome some negative images in the past and, especially, in what ways it can continue to contribute to contemporary spiritual life.

This essay will contribute to this new interest in the spiritual practice of Sabbath keeping. This essay will also investigate recent interest in the spiritual practice of Sabbath keeping. It will focus, firstly, on the spiritual nature of Sabbath keeping in Biblical texts and its reception in Judeo-Christian traditions. It will spell out comprehensive, multifaceted approaches to Sabbath keeping and Sunday observance in these traditions and show how dynamically these approaches were developed in terms of later contexts. It will then analyse the positive impact of this spiritual practice on human relationships, and, then explore, especially, its spiritual nature as its most essential dimension. This will reveal how transformative Sabbath keeping as a spiritual practice can be even in contemporary contexts. The aim of the article is to investigate insights that Spirituality authors can gain from past history, in order to respond meaningfully to challenges in their own context and to empower them to counter the serious consequences for the spiritual health of those who are victims of a consumerist culture. ${ }^{3}$

3 Cf. further Marchinkowski and De Villiers (2020) for a general discussion of spiritual practices in recent times and their dynamic nature. 


\section{Judeo-Christian perspectives}

Much of Sunday observance in Christian contexts is illuminated by passages from the Hebrew Scriptures on the Sabbath, because Christianity, rooted in a Jewish context, also observed it as a spiritual practice and based their practice on Biblical insights. This practice changed with the expansion of Christianity into non-Jewish contexts. There are differences between the two traditions: The Sabbath was abandoned by some Christian groups, or changed into Sunday observance by others. Still other differences were results of later movements within Judaism, beginning with Rabbinic traditions that instituted certain new rituals and regulations (cf. further below) that were not taken over by Christian communities. Certain Christian groups rejected Sabbath keeping because of their anti-Jewish sentiments or on the grounds of historical or theological beliefs about Sunday as the day of the resurrection. There remain, however, some key motifs in both the Jewish and Christian practice. This must be investigated in more detail now by analysing the early Jewish and Christian practices of Sabbath keeping.

\subsection{The Jewish Sabbath in history}

Judaism is united on the basic tenet that the Sabbath is the central ritual observance of Jewish life, even though there are disagreements between various Jewish groups on what it means to observe the day. ${ }^{4}$ On the most abstract level, the Sabbath belongs to the heart of Judaism and is a key marker of Jewish identity, ${ }^{5}$ signifying the covenantal relationship between God and God's people (Ex 31:12-17). ${ }^{6}$ It represents an opportunity for the faith community to experience the closeness of God both in communal

4 Cf. the introductory remarks in Fleischacker (2017). The Jewish author, Abraham Joshua Heschel, writes (1951:8), "The Sabbaths are our great cathedrals."

5 Other identity markers are circumcision, dietary laws and endogamy. For a full discussion of literature and the wider contexts in which these markers function, cf. Holmberg (1998), Andreasen (1972) and Robinson (1988). Cf. also Bass (1997:79-80) on this important aspect from the perspective of spiritual practices.

6 Heschel (1951:16) writes, "What would be a world without Sabbath? It would be a world that knew only itself or God distorted as a thing or the abyss separating Him from the world; a world without the vision of a window in eternity that opens time." 
and family contexts. ${ }^{7}$ Its importance is illustrated on the most basic level by the fact that it is one of the Ten Commandments and, that it is presented so extensively in the Decalogue (see further below). Sabbath keeping in Judaism is, therefore, about transformative relationships of the divine with humanity rather than about doctrine. ${ }^{8}$ It is in the first instance about the lived experience of faith that affects one in all the various dimensions of human existence. It is about a practice that changes, heals, affects and integrates one in a meaningful life. In this regard it is much more than simply another belief or teaching.

Biblical texts do not provide much information on how the Sabbath should be kept, despite its central role in the religious discourse of that time. In post-biblical times, rabbinic and orthodox Judaism first provided a detailed web of laws that gradually expanded to include various matters like resting, eating, playing, conversing, reading for pleasure, sexual intercourse (Bass 1997:81; Fleischacker 2017). ${ }^{9}$ This intensification of rules is not necessarily a negative development, though they, at times, did take on a legalistic and even oppressive character - as the Gospel announcements about the Sabbath would reveal (cf. below). Rowland (1982) offers an extensive discussion of early Jewish perspectives on the Sabbath. He concludes (1982:53) that the many regulations reflect a desire to obey the Law in periods that differed from biblical times. "The complexities of Jewish sabbath practices are to be understood as sincere attempt to translate the revealed will of God

7 Fleischacker (2017:121) notes that the Sabbath is first and foremost about a family and community building practice. He writes, referring to the careful preparation for the Sabbath meal, "There is thus a 'shabbat-conciousness' that runs through one's life. This again serves as a mark of communal and religious identity, and an opportunity to allow the closeness of God one experiences on Shabbat to infuse one's mundane experience as well."

8 Cf. Pacner (2013:1-23) for the Shabbat as sign of the divine relationship with Israel. With its instruction to refrain from work, it also represents a day of freedom.

9 Cf. also, much later, laws regulating the use of technology. Cf. for this Fonrobert (2005). The book of Jubilees (50:12b-13a) lists the following prohibitions: Someone who does any work thereon, or goes on a journey, or tills a farm, whether in his house or any other place, and whoever lights a fire, or rides on any beast, or travels by ship on the sea, and whoever strikes or kills anything, or slaughters a beast or a bird, or whoever catches an animal or a bird or a fish, or whoever fasts or makes war on the Sabbaths: The man who does any of these things on the Sabbath shall die, so that the children of Israel shall observe the Sabbaths according to the commandments regarding the Sabbaths of the land. The book also prescribes the death sentence for violations of the Sabbath (2:27; 50:13b; Charles 1913: ad loc.). 
into the complex social setting of the Hellenistic world." The very attempt to regulate human actions reflects a response to the call in Biblical texts to sanctify the Sabbath and to allow it to have its optimum effect on the spiritual journey of faith communities.

The particularities of these requirements to a large extent depended on the religious context in which Sabbath was celebrated. That is why Sabbath keeping varies among Jewish groups. It is more regulated in orthodox communities where the laws are more extensive than in Reformed Jewish communities. ${ }^{10}$ Marks et al. (2017:4) writes, "An Orthodox family would view Shabbat as a chiyuv or non-negotiable obligation, a Reform or Conservative family might be more flexible and negotiate around events and conflicts that arise from secular culture." This indicates how communities wished to integrate their sacred traditions about the Sabbath in a living, dynamic way with their spiritual life. It had to be relevant to who they were and to their search for meaning in their own context. This perspective is important, because it indirectly suggest that modern appropriations of Sabbath keeping will by necessity take on new, unique forms.

Despite these variations, families in all these traditions celebrated the Sabbath in one way or the other, further confirming its significance for Jewish life. An outstanding feature of all these groups is that they linked Sabbath keeping with relieving believers of their daily work in order to worship God (Dressier 1982:26). In due course, the Sabbath meal that represents a joyful end to the working week and the beginning of the day of rest, became an important tradition of Sabbath keeping. ${ }^{11}$ The celebration of the Sabbath in Judaism with its ritual meal displays a pattern that speaks of intimacy, belonging and homeliness within the trusted context of family and friends. Traditionally the Sabbath begins in a Jewish home at sunset on Friday. The celebratory meal, developed from rabbinic times, involves the lighting of candles, making braided bread, setting a beautiful table, having

10 The more progressive Reformed Judaism expresses reservations about Sabbath laws that it regarded as compromising the freedom that is so important to the Sabbath day. "The ancient rabbis knew that excessive piety may endanger the fulfilment of the essence of the law" (Heschel 1951:17).

11 Cf. Gribetz (2019) for a discussion of the Shabbat meal in Judaism and its link with Biblical texts. 
traditional foods and following a liturgy with singing and prayers. ${ }^{12}$ In some instances, the blessing of children is an important part of the meal. ${ }^{13}$

It is one of the abiding contributions of the meal in Jewish traditions that it is directly relevant for communal relationships and serves as a corrective to the devastating impact of the driven society on family life. A strong sense of this meal is that of a joyful family occasion in which both adults and children actively participate. ${ }^{14}$ People find rest and well-being in the cessation of daily work and in the warmth of family togetherness. Children are especially confirmed in their unique place in the family when they receive the blessing. All these aspects underline the positive nature of Sabbath keeping in its focus on the well-being and flourishing of the family.

The meal plays a very positive role in family life as a social entity, as a recent empirical study strikingly revealed. ${ }^{15}$ Interviews with participants in this study indicated that the meal promoted family cohesion and togetherness (Marks et al. 2017). It had an inclusive, intimate nature that brought stability to family life in the midst of an often fragmented, restless, and overworked society. ${ }^{16}$ There are hurdles to be crossed, as the interviews revealed. But persisting with the practice, despite resistance among family members because of their commitments and involvement in other matters, bears much fruit because it brings individuals together and solidifies family life. Sabbath keeping in this context requires dedication and discipline. It is a practice, to be kept regularly, exactly because of human weaknesses and failures.

Valuable as this contribution is to a more stable society and family life, the practice ultimately and more significantly, reflects deeper dynamics. The

12 Cf. Marks et al. (2017:3) and Smith-Gabai and Ludwig (2011:348-9) for an extensive description of the rituals and the meal.

13 Bass notes (1997:80) how "parents will bless their children and give them a bit of sweet spice so that the taste of Sabbath peace will linger on their tongues."

14 Cf. the introduction to Heschel (1951:8), written by his daughter, which provides a special insight in the celebration of sabbath by a Jewish family.

15 Cf. Marks et al. (2017) for the report of the various responses of participants in the meal. This empirical survey reveals the ongoing relevance of Sabbath keeping in contemporary society. The research is also helpful because it also spells out the challenges to and negative experiences of the Sabbath meal.

16 Cf. Marks et al. (2017). They point out how practitioners of Sabbath keeping feel strongly about how it enables families to spend time together and how it promotes family unity. 
results of the above-mentioned study showed that participants cherished the practice of the Sabbath meal not merely for its benefits for family life. Their comments reflect an awareness of the ultimacy about which it speaks. The simple act of giving up of work, the practical arrangements for the family meal, and the actual sharing of food were special, but the meal was also about resting in and worshipping God and about being close to God in a relationship that transforms the self. In the encounter, it is not only about individual transformation. In this transformation there is a deepening of relationships with other participants at work. ${ }^{17}$ Moreover, Sabbath keeping is not merely being busy with spiritual things or reflecting on spiritual matters. The practice is, therefore, in itself a spiritual act, assuming selfimplication, transformation and commitment.

This spiritual side of the meal with its rituals on a micro-level, was linked with rituals of worship within a larger communal setting: Sabbath keeping included attending synagogue services where the Torah was read and interpreted (Marks et al. 2017:3). It reflects the desire to share the divine presence in community with each other, but also to engage with the divine voice in Scripture and teaching.

The reception history of the Sabbath thus accentuates its positive spiritual meaning and suggests why it retains its ongoing relevance in Judaism up to the present day. At the same time, the above-mentioned empirical survey shows that the ancient practice can still appeal to faith communities today. Though the survey points out that, as with all practices, it can sometimes evoke negative feelings and resistance; it reveals how perseverance and openness to its religious nature, help to facilitate recognition of its healing and fulfilling nature in the midst of a fragmented, driven societal context. What is needed is to focus on its positive outcomes, hold on to it with discipline and persistence and, more importantly, to approach it in terms of being in the divine presence. On a still deeper spiritual level, it invites one to celebrate the unique and gracious gift of existence. It is about celebrating being.

17 Fleischacker (2017:121) underscores this transformative impact of Sabbath as spiritual practice. What is needed, though, is to spell out this transformation in more detail. One aspect would be that the meal transforms a family from fragmentation to mutual appreciation, thus creating cohesion which tends to be lost in and because of a hectic lifestyle. 


\subsection{The Christian Sunday in history}

The relative lack of interest in Sabbath keeping in contemporary times is not entirely surprising. Both the Sabbath and Sunday played a significant role in the history of the Christian church. This statement should be read with a caveat: one should not idealize or romanticise Sabbath keeping as a spiritual practice. It has not always been regarded positively. In fact, at times it was regarded with hostility by those who held anti-Jewish sentiments and wished to position Christianity over against Jewish customs and groups. Victorinus, for example, wrote in his On the Creation of the World 4 in the third century, that Christians did not practice Sabbath keeping because they did not want to be regarded as Jews. He thus stigmatized the Sabbath as a Jewish custom. ${ }^{18}$ This was a recurrent thread in the history of Christianity. Much later, for example, Martin Luther, the influential Reformer, would share the same sentiments. It must also be mentioned how church folk would rebel against or ignore Sunday observance in many places and times, much to the chagrin of their spiritual readers. The relative role of the Sabbath is also clear from the fact that eventually Christianity began to replace Sabbath keeping with Sunday worship and, later Sunday observance. All this will become evident in the following discussion where the Christian reception of Sabbath keeping will be discussed.

\subsubsection{Sabbath and/or Sunday}

The Christian church has always been aware of the way Jesus upheld and confirmed the Jewish law and kept the Sabbath. The followers of Jesus also observed the Sabbath commandment, as is explicitly mentioned in the Gospel. The Sabbath figures prominently in the Gospel narratives in connection with the resurrection of Jesus, reflecting their awareness of its importance and binding character. Luke 23:53-56 and 24:1 describe how Jesus was buried on Friday as the Sabbath "drew near," confirming that the disciples wanted to avoid breaking the law about what should not be done on the Sabbath. The disciples then retreated to celebrate the Sabbath as a day of rest, which was also described by the explicit remark that "They rested on the Sabbath according to the commandment." They only visited the grave on "the first day of the week."

18 Similar pronouncements in Ignatius's Letter to the Philippians 13-15 and the Letter to the Magnesians 9. Also, Diognetus 4, Tertullian's On Idolatry 14 and many others. 
These verses show that the early Christians followed the example of Jesus and observed the spiritual practice of Sabbath as a day of rest. How they spent the Sabbath concretely, remains largely unknown. That they accorded it a special place is evident from their reference to the participation of Jesus in Sabbath proceedings. Nevertheless, they also noted critical pronouncements of Jesus regarding Sabbath keeping, for example, in Mark 2: 23-28, where Jesus states that the Sabbath is not intended as a means of controlling the behaviour of people, but rather as a way of helping or blessing humanity. In addition, Jesus asserts his personal authority over the Sabbath when he heals on the Sabbath (Mk 3:1-6, Mt12:9-14, Jn 5:1-24 and 9:1-41).

These pronouncements show how Early Christian communities revised and transformed Sabbath keeping in the light of the ministry and proclamation of Jesus (Olson 2008:24). This confirms how dynamic sabbath keeping is, having been modified because of the new situation that came about with the day of the resurrection (Bass 2000:54). It also shows their understanding of the spiritual nature of Sabbath keeping: Jesus's criticism of the Pharisees indicated that the Sabbath was about compassion, freedom and human flourishing (Mk 2:27). Their critical understanding of the Sabbath laid the foundation for later forms of celebrating Sunday.

Here, too, matters are not simple. Sunday as day of worship within the faith community is obviously a later development in the history of Christianity. There are several indications in Early Christian texts that Christians began to meet on Sundays early in the second century. ${ }^{19}$ De Jonge (2016:578) argues that various passages in early texts like Acts (20), Ignatius, the Didache, Justin and Tertullian show that Christians had their assemblies and common meal on Sundays. This does not mean that they celebrated the Sunday as a new Sabbath, that the eucharist replaced the family supper on Sabbath or complemented the Sabbath gathering in the synagogue. It does

19 An overview of the debate can be found in Sturcke (2005), 17-32. Cf. further also Rordorf (1968) and Jewett (1971). Cf. Bauckham (1982:230), who writes, "From the later second century onwards it is clear that Sunday was the regular day of Christian worship everywhere, and there is no record of any controversy over whether worship should take place on Sunday." McIver (2015). Cf. also Ignatius of Antioch, Epistle to the Magnesians 9:1-2; Didache 14:1for early references to Sunday meetings of Christian communities. 
not make sense that such a Sabbath supper would be shifted to the Sunday morning and, later, to the Sunday evening, and, also, that the Sabbath meal would be followed by a second full meal on the same evening or in the same night. He adds, "(A)ll this does not mean that the Christian eucharist can be regarded as emanating, directly or indirectly, from a Sabbath meal or from the synagogal meeting on Sabbath devoted to the study of the Law."

De Jonge does, however, and more importantly, acknowledge that there were similarities between the two,

True, its weekly periodicity was based on that of the observance of the Sabbath. The custom of saying grace before and after the meal was analogous to the practice of blessing or thanksgiving at meals as observed by many Judaeans. In certain cases, the Christian prayers of thanksgiving could even resemble those said in Judaean circles. ${ }^{20}$

Sunday meetings thus kept alive the special place of the seventh day in the weekly cycle of days and the motif that one of the seven days represents a day of reflection on and celebration of the spiritual traditions of the church. Somehow the Sunday celebration of Christians resonated with the Sabbath keeping in Judaism.

All this should caution one from equating the Sabbath and Sunday worship too simplistically. There are, for example, indications that some groups abandoned Sabbath keeping as a Jewish law that did not bind Christians. Sturcke (2005:17-32) and Dieleman (2019:15) both argued that one should not too easily assume that most early Christians observed the Sabbath and then infer that Christianity did the same. In addition, there were many forms of Sunday observance. Sturcke notes in his investigation of several Biblical and extracanonical texts that there was a marked diversity in attitudes of early Christian groups towards Sabbath keeping, whilst Dieleman (2019:15) observes, "However, Sunday observance has not been uniform throughout

20 Instead of linking the Sunday gatherings with the Sabbath, De Jonge (2016:578) hypothesized that Sunday meetings in the early first century may have taken place in imitation of the popular parties of the many voluntary associations in the Hellenistic world. Christians created their own community feasts in response to these. Cf., however, Bauckham (1982) for a different version of the origins of Sunday worship. He places it in a Palestinian Jewish-Christian context and interprets it as a commemoration of the Resurrection on the first day of the week. 
the Christian tradition, and the theological issues related to the Sabbath are surprisingly complex." 21 Different groups prescribed different ways rules for behaviour on the Sabbath, or used different motivations for keeping these rules. Much depended on the context in which these groups and authors lived and what their convictions and teachings were - just as was the case within Jewish groups (cf. above).

Nevertheless, it needs to be emphasized that most Christian groups in some way or another remained aware and /or observant of the Sabbath. Common to these groups was that they held Sundays in special regard as the Day of the Resurrection. They were, however, not rigorous in their practice. Their attitude displays the openness in the Pauline tradition, which implies that Paul rejects any attempt to forbid believers to observe Sunday as the Christian day, but he also forbids anyone from forcing believers to keep Sunday (De Lacey 1982).

The real turning point in the history of Sabbath keeping was when Sunday was embraced formally as the Sabbath in the time of Emperor Constantine who legislated in 321 C.E. that the Sunday (the Lord's Day) should be a day of rest from work for the whole empire (Bass 2005:25). ${ }^{22}$ This further solidified the understanding in mainstream groups of Sunday as replacing the Sabbath. ${ }^{23}$

\subsubsection{Keeping the Sabbath on Sunday}

The view of Augustine was especially influential after Constantine's time. Augustine stressed that Sabbath commandment, as part of the Decalogue, had an abiding validity as the norm of Christian morality. He did, however, spiritualize the commandment, stating that it was not about keeping a

21 For a helpful overview of Christian attitudes towards Jews, including the Sabbath cf. Veldt (2007).

22 For an extensive discussion of Constantine's role in this regard, cf. McIver (2015). He notes (30): "There is, in fact, evidence that can be put forward to support the claim that Constantine was a crucial player in the shift of the day of worship from Sabbath to Sunday."

23 Even here one should be nuanced, because there were groups that still maintained Sabbath keeping next to their Sunday meetings. For arguments, cf. McIver (2015:19, 32). One brief example of the celebration of both days is to be found in the Apostolic Constitutions 8.4.33 that notes that slaves should attend church on the Sabbath and Sunday. 
day and literally refraining from work. To rest was, for him, to be in the presence of God - in the sense of Psalm 46:10 ("Be still and know that I am God"). The Sabbath was spiritualized in the sense that its meaning for the spiritual journey was underlined: Sabbath keeping referred to the eternal rest in the eternal Sabbath (Bauckham 1982b:299). It is not literally about the seventh day but had to be celebrated on a Sunday as the Lord's day on which one had to refrain from work and attend worship service.

This was the position throughout the Middle Ages. This tradition has been reaffirmed, for example, in a papal letter by Pope John Paul II on Sabbath keeping. He wrote this comprehensive letter, Dies Domini, in 1998 in which he recounted the importance of Sunday by referring to its place in Biblical texts, in the early history of the church, and in later times, with a culmination in the statement of the Second Vatican Council. The letter quotes Ignatius of Antioch and Augustine in paragraph 23 to argue the distinction between the Sabbath and Sunday in the light of the resurrection on the Lord's day. It notes how this distinction "ever grew stronger in the mind of the Church." The Sabbath had to be kept as a moral law, but on the Lord's day. Sabbath keeping has a binding character for all times, but it is replaced by Sunday as Resurrection day.

The letter opens with the remark that Sunday "has always been accorded special attention in the history of the Church because of its close connection with the very core of the Christian mystery. In fact, in the weekly reckoning of time, Sunday recalls the day of Christ's Resurrection." The letter then notes the statement by the Second Vatican Council, "Every seven days, the Church celebrates the Easter mystery. This is a tradition going back to the Apostles, taking its origin from the actual day of Christ's Resurrection a day thus appropriately designated 'the Lord's Day'." ${ }^{24}$ Sunday is closely linked to the Eucharist. This link is why the papal letter notes in paragraph

24 Paragraph 3 begins with the remark, "The fundamental importance of Sunday has been recognized through the two thousand years of history and was emphatically restated by the Second Vatican Council" and paragraph 7 states, "Sunday is a day which is at the very heart of the Christian life." Apostolic letter dies domini of the holy father John Paul II to the bishops, clergy and faithful of the catholic church on keeping the Lord's day holy. [Online]. Available: http://www.vatican.va/content/john-paul-ii/en/ apost_letters/1998/documents/hf_jp-ii_apl_05071998_dies-domini.html. 
5 that attendance of the Sunday liturgy is low because there is a diminishing sense of the centrality of the Eucharist.

Like many other contemporary authors that wanted to reinvigorate Sabbath keeping, the Pope also referred to the secularising of society as a trend that could be countered by upholding the celebration of Sundays as day of rest. ${ }^{25} \mathrm{He}$ encouraged Roman Catholics to remember the importance of keeping Sunday holy, urging them not to lose its meaning by allowing it to be blended with a frivolous "weekend" mentality. Sabbath keeping is promoted as a practice that offers a spirituality that runs counter to the secularisation of society.

This letter offers a succinct summary of the understanding of Sabbath keeping in Roman Catholicism over many centuries. It reflects the high regard with which the Sabbath was held during this time and its close association with the Day of the Lord' resurrection, and especially with worship and the eucharist. This tradition thus breaks with the type of detailed regulations that existed in later Judaism.

\subsubsection{From pragmatism to Sabbatarianism}

Protestantism is of special importance in the investigation of Sabbath keeping because it brought significant changes to how Sundays were to be observed. Protestants referred to Sunday also in terms of the Sabbath and regarded Sunday in terms of the resurrection as the Lord's day. Reformers like Martin Luther and John Calvin did not separate the Sabbath from the Lord's Day in their writings. They reacted against a legalistic observance of Sunday, with Luther noting that the Sabbath commandment was meant for the Jews and not for Christians. They had a pragmatic approach to Sundays: It is necessary because people have to rest, and it makes sense to have Sunday as a day for worship on the day when people are not working. ${ }^{26}$

25 Paragraph 4 of the letter states, "Until quite recently, it was easier in traditionally Christian countries to keep Sunday holy because it was an almost universal practice and because, even in the organization of civil society, Sunday rest was considered a fixed part of the work schedule. Today, however, even in those countries which give legal sanction to the festive character of Sunday, changes in socioeconomic conditions have often led to profound modifications of social behaviour and hence of the character of Sunday."

26 For Luther's positive view of the Sabbath as time for worship, cf. Kaiser (2013:135): "According to Luther, the Sabbath was intended as a time for divine worship, for the 
The Reformers, given their doctrinal position, rejected the centrality of the eucharist and called for church folk to worship. For them this meant listening to the proclamation and preaching of the Gospel (Bauckham 1982:316-7; Kessler 2012:6). ${ }^{27}$ There was, therefore, some commonality with Roman Catholicism in stressing the importance of Sunday as a day of worship, but it was a day of hearing sermons and receiving catechism teachings, with ecclesiastical discipline being exercised where the day was not properly observed (Dieleman 2019:15).

Another movement in Protestantism after the Reformation represents a new development in the practice of Sunday observance and, remarkably, the restoration of Sabbath observance in a literal sense of the word. In some cases, Sunday is literally abandoned in this tradition and the Sabbath reinstated as day of rest and worship. This phenomenon of Sabbatarianism that promoted strict rules and observances for the "Lord's Day," was a response to a perceived laxity in the observance of Sunday among Christians. ${ }^{28}$ These groups called on Christians to follow the Scriptural injunctions more strictly in breaking from work and meeting for worship and prayer. Their approach was not pragmatic, focusing on how sabbath keepings should be done, but theological, attending to the meaning of Sabbath keeping: It was a binding commandment. Collinson (1964:207) wrote that in this period groups asserted that "the fourth commandment is not an obsolete ceremonial law of the Jews but a perpetual, moral law, binding on Christians; in other words, that the Christian observance of Sunday has its basis not in ecclesiastical tradition but in the Decalogue." The term "Sabbath" was then regarded as the equivalent of older terms such as the "Lord's Day" or "Sunday." 29

preaching and hearing of God's Word, and for the growing relationship with God. The Sabbath points believers specifically to God's goodness for, on that day, he continues to keep the universe in motion, and to govern and preserve the realm of human life. All this happens through the constant benevolent activity of the Word. God's creative, preserving, and governing activities make believers wonder at his power. "Cf. also Bauckham (1982:312-313) for Luther's argument that the Decalogue is binding on Jews only.

27 For the disputes about the Sabbath among Reformers and about their criticism of seventh day keeping Anabaptists, cf. Augsburger (1982).

28 Cf. the extensive discussion with many examples in Orr (s.a.) and Kessler (2012:6).

29 Cf. Dieleman (2019). His empirical research on Sunday observance is illuminating in so far as he traces actual examples and practices in local church documents that 
According to often repeated statements, Protestant Sabbatarianism was prominent in Anglo-Saxon contexts during the 16th to the $18^{\text {th }}$ centuries. Puritans and Baptists in England and Scotland are often said to have introduced Sabbatarianism (Kessler 2012:6). ${ }^{30}$ Such Christian groups observed Sunday with strict prescriptions and laws similar to that of Judaism for the Jewish Sabbath. ${ }^{31}$ It is also often argued that this reflected political differences, as if Sabbath keeping were a way for these mostly non-Conformist groups to distinguish themselves from their Catholic opponents. This form of Sabbatarianism is sometimes called first day Sabbatarianism (in contrast to Seventh day Sabbatarianism).

Recent research has indicated, though, that they were not the first or the only ones to have promoted Sabbatarianism in England. Parker (1984:3358) listed examples of earlier non-Puritan authors who regarded Sabbath keeping as a moral commandment that, other than Jewish ceremonial instructions, had perpetual and binding authority. They criticised people who did not refrain from working and indulged in extravagant and vulgar unspiritual behaviour on Sundays. This shows that Sabbath keeping was firmly established in England across denominational borders and not unique to Puritan groups. So prevalent was Sunday observance among all groups that Katz (1988:xi) refers to an author who remarked in 1659 that "the religion of England is preaching and sitting still on Sundays." 32 This Sabbatarian stream once again shows how Sabbath keeping takes on

show how Protestant churches in the Netherlands disciplined their members to attend worship services because of their strict theological perspectives on the Sabbath.

30 Weeks (2011:267ff.) offers an overview of the tradition of Sabbatarianism in England and the United States. He notes, however, that Sabbatarianism was well established since the latter part of the sixteenth century, before Puritanism became influential. Cf. also the remarks of Parker (1984) about such earlier forms of Sabbatarianism. $\mathrm{He}$ also argues that Sabbatarianism was not a Puritan innovation. For the history of Sabbatarianism in seventeenth century England, cf. Kats (1988). He notes how the Mosaic Law had a binding authority for many in England. This determined Sunday observation decisively. Cf. also Parker (1984).

31 Note, however, that Bullinger was the first Protestant theologian who discussed in detail what may or may not be done on Sundays. This included such detail as not sleeping late. Cf. Bauckham (1982:318).

32 He adds that Sunday observation, "devoted to religious education and abstinence from ordinary weekly activity was one of the most distinguishing features of English religious life" and "was radically different from what prevailed in Protestant areas on the Continent." 
various forms. In this case, the established church in England displayed both Sabbatarian and non-Sabbatarian views of Sabbath keeping.

The respect for Sabbath keeping in this early modern period is evident on a much larger scale. Recent research reveals how significant Sabbath keeping was in other countries as well. The literal observation of the Sabbath as binding, natural law was common elsewhere in Europe. Dieleman (2019:23ff.), for example, having investigated primary sources of local churches in the Netherlands, concluded that strict Sabbath observance was a significant early phenomenon in Dutch Reformed contexts: He notes, "It is my contention that in the sixteenth and seventeenth centuries the Sabbath was an integral aspect of Christian piety in the Dutch Reformed tradition. The Sabbath became for Dutch religious authorities a way to ensure order within the church but was also a way to distinguish Reformed Christians from Catholics and Anabaptists.” This observation is new, because official documents or creeds do not always reflect this key role of the practice in the piety of Reformed communities. This research also questions the assumption that Puritans introduced Sabbath keeping. Recently we came across a forgotten, but still informative discussion in Bacher (1890) who draws attention to the widespread nature of Sabbatarianism in Hungary and in Eastern Europe (among the Soboniki in Russia) with their practice of circumcision, their rejection of Christ's divinity and their embrace of the Mosaic law, with the Sabbath as its most characteristic feature. Clearly, the strict form of Sabbath keeping was popular across various countries in that time. It was endemic to the experiential reality of many faith communities.

This situation would continue up to modern times. Sabbatarianism flourished and peaked with the even more strict and literal form of Sabbath keeping in, for example, Seventh Day Adventist (S.D.A) churches in the United States. ${ }^{33}$ It was established in this group after the Great Disappointment when, after the failed prophecy of the return of

33 Cf. Bacchiochi (1982) for a discussion of Sabbath keeping from an Adventist perspective. The Seventh-day Adventist Church in early American history was preceded by Sabbatarians like John Traske (1586-1636) and Thomas Brabourne in England. [Online]. Available: https://en.wikipedia.org/wiki/Sabbath_in_Christianity\#Sabbatarian_ churches. 
Christ in 1844, some members of the Millerite movement, ${ }^{34}$ influenced by visions of Ellen G. White, argued that the return did not take place because faith communities failed to observe the Sabbath on the seventh day. This explanation of the Great Disappointment would contribute to the establishment of the Seventh Day Adventist church, with, currently, a membership of 18 million.

It is noteworthy how far this seventh day Sabbatarianism spread in Protestant locations. Sokupa (2015) in his essay on Sabbatarianism in South Africa, points out that it came to South Africa mostly via American Baptist connections early in the twentieth century. He notes, for example, how some of the S.D.A. members were victimized in the country because they promoted Saturday as Sabbath. He quotes from a letter by Moko, a missionary in the Seventh Adventist church at the beginning of the twentieth century, who wrote about a new member, "The first to keep the Sabbath received a hard beating from her husband, and was sent to her parents. The latter brought her back and a council was held, with the result that the woman was allowed to keep the Sabbath."

In general, though, Sabbath keeping is not restricted to groups on the fringe of the religious scenario. Mainline Protestant churches have reaffirmed the importance of the Sabbath. Sunday is declared a holy day of rest, for example, in the Calvinist Westminster Confession of Faith (1646) 21:7-8 (Of Religious Worship, and the Sabbath Day), which reads that God

in his Word, by a positive, moral, and perpetual commandment binding all men in all ages, ... hath particularly appointed one day in seven, for a Sabbath, to be kept holy unto him: which, from the beginning of the world to the resurrection of Christ, was the last day of the week; and, from the resurrection of Christ, was changed into the first day of the week, which, in Scripture, is called the Lord's day, and is to be continued to the end of the world, as the Christian Sabbath.

This required that Christians

34 William Miller (1781-2849) came from a Baptist background, Ellen White was Methodist. For a discussion of research on Seventh Adventism, cf. Reynaud (2016:5461). 
observe a holy rest, all day, from their own works, words, and thoughts about their worldly employments and recreations, but also are taken up, the whole time, in the public and private exercises of his worship, and in the duties of necessity and mercy.

It is striking that this confession deviates from the Reformation by understanding the Sabbath as a moral law that is still binding, that Sunday is the "Christian" Sabbath and that it is primarily a day for worship.

This high regard for Sabbath keeping also continued in unexpected contexts at much later times. This became evident in a study of Weeks on Sabbath keeping in Presbyterianism in the United States (already in 1981). That study showed the central role of Sabbath keeping in Presbyterianism.

\section{Conclusion}

This overview reveals the ongoing relevance of Sabbath keeping in faith communities throughout history, despite the times that it seemed to have been neglected or downplayed.

- The overview showed the changes in Sabbath keeping. Protestantism, for example, represents a new phase in the history of Sabbath keeping. The Reformers' Sabbath keeping initially emulated the practice as it was kept in early Christianity - reflecting their Sola Scriptura approach that Biblical texts only determine the spiritual life. There were stark differences, however, even among them. A good example is the work of Heinrich Bullinger, the Swiss Reformer, who had a rather unique view: he wanted all people, not just believers, to keep the Sabbath, he called on the civic authorities to oversee that it was obeyed and argued that it was a moral injunction with perpetual obligation. ${ }^{35} \mathrm{He}$ was influential especially in Puritan circles in England - which would help explain their Sabbatarian convictions.

- The overview also showed the ongoing relevance of Sabbath keeping. Even if not many churches resorted to literally keeping

35 Cf. the discussion in Lee (2014), who writes, "Being one of the most widely read of the continental reformers, Bullinger's influence was far reaching. In England, the impact of his Decades was felt on generations of pastors and theological students. Bullinger's Sabbatarian theology introduced many themes that are clearly repeated throughout the works of many English Puritans.” 
the Sabbath, they did hold Sunday observance in high regard, insisting on resting from secular activities and engaging in spiritual matters. In fact, throughout history Sabbath keeping determined the experiential reality of believers. If it was by times not discussed much in theological discourse, it was certainly important in the praxis of faith communities. What Dieleman (2019:16) wrote about Dutch Protestantism, is to a certain extent true of the whole of Protestantism, of Roman Catholicism, Eastern Orthodox communities and even of Christianity in general: "Attending to the Sabbath in the Dutch Reformation is necessary for understanding more completely how the Protestant Reformation impacted the lived religious experience of Christians.

- The overview also provides fascinating insights into the relationship between theology and religious practice and how that relationship was navigated." Dieleman (2019:21) notes that his study of church records shows how theological ideas impacted historical practices and discipline and how the Sunday practices of Dutch congregants influenced theology. It is, however, true of other instances and contexts too that religious ideas powerfully determined the praxis, ${ }^{36}$ even in politics. In England, for example, people "who on political grounds should have been the most bitter of enemies, including millenarians, Fifth Monarchists, neutrals and Royalists alike," united on the ideological foundation of the ongoing validity of the Mosaic law, celebrated the Sabbath on Saturdays. They overcame their political differences because of their religious convictions and their assumption that the Bible was literally true. This is an ironical indication of the cohesive function of Sabbath keeping.

- The previous remarks are also helpful in the sense that they illustrate the central role in the religious discourse. There are certain important commonalities between the various groups that are helpful in reflecting on contemporary forms of Sabbath keeping: They all underlined the need to retain a rhythm of activity that allows for

36 A major issue was, for example, whether instructions on Sabbath keeping in Hebrew Scriptures had binding authority for Christians. Also significant was the interpretation of the commandment that the Sabbath is a day for "resting," that is resting physically, or resting spiritually. 
work and rest. The "rest" is not only about physical renewal. It is also about finding a restful space and time away from the hustle and bustle of the daily routine. Such rest allows one to discover the deeper dynamics of existence and assists in discovering what makes sense. It is the space in which one regains perspective on who one is and what keeps one busy. It speaks of life beyond sweat and toil in the communal setting of family and friends that is experienced in sharing the most mundane activities of being together, sharing, celebrating, speaking, praying and affirming others in their humanity during meal times, but also in worshipping in synagogue or church. Life can be about very concrete, simple things that bring joy and give meaning. The rhythmic nature of the practice that characterises the practice in all traditions, indicates how necessary it is to renew this act of distancing, especially when one is preoccupied with and pressurised by so many mundane activities. It allows one to discover what role work and, by implication, the mundane play in the gift of life that is granted to creation and its creatures. One discerns from this rhythm that meaning that is to be found outside and above mundane matters, behind all the daily toil and sweat.

- Sabbath keeping is, as the overview reveals further, a "spiritual" practice, that is, an activity that is integrated in the divine-human relationship and that is meant to transform those who desire to remain in the relationship. It is not about legalism, rulemaking or authoritarian instructions and control. This clear from the bond with the sacred traditions as it is called to mind in rituals and communal meetings and that speaks of holding on to faith as it was lived in the past, about remembering Scripture's narratives about the Sabbath and the Lord's day. In doing so, it is about an encounter with the divine presence that empowers one to stand back, survey creation and discover what is good. Such distancing brings with it appreciation for the beautiful gift of life, even and in the midst of all the challenges that life brings with it. And it should also provide light on what really matters, what brings ultimate joy. Where this happens regularly, life flourishes. It is a practice that keeps on making one aware of the Giver of life, the Creator of what is good, the graceful presence of the One who brings into existence, sustains the creation and renew it in so 
many ways and places. God knows how necessary it has been for the world to keep such a life-enhancing practice.

\section{Bibliography}

Augsburger, D.A. 1982. Pierre Viret on the Sabbath Commandment.

Andrew University Seminary Studies, 20, no. 2: 19-101.

Bacchiocchi, S. 1982. Divine rest for human restlessness. Hamburg: Advent-Verlag.

Bacher, W. 1890. „The Sabbatarians of Hungary.” Jewish Quarterly Review, 2, no. 4:465-93.

Bass, D.C. 1997. "Keeping Sabbath," in C. Dykstra and D. Bass (eds.), Practicing our faith. A way of life for a searching people. San Francisco: John Wiley. 75-89.

-.2000. Receiving the day. Christian practices for opening the gift of time. San Francisco: Jossey-Bass.

- 2005. Christian formation in and for Sabbath rest. Interpretation, 59(1), 25-37.

Bass, D.C. and C. Dykstra. 2002. "A theological understanding of Christian practices," in D.C. Bass and M. Volf (eds.), Practicing theology. Beliefs and practices in Christian life. Grand Rapids: Eerdmans.

Bauckham, R.J. 1982a. "Sabbath and Sunday in the Post-Apostolic Church," in D.A. Carson (ed.), From Sabbath to Lord's Day: A Biblical, Historical and Theological Investigation. Grand Rapids, MI.: Zondervan. 251-298.

-. 1982b. "Sabbath and Sunday in the Medieval Church in the West," in D.A. Carson (ed.), From Sabbath to Lord's Day: A Biblical, Historical and Theological Investigation. Grand Rapids, MI.: Zondervan. 299310. 
-. 1982c. "Sabbath and Sunday in the Protestant tradition," in D.A. Carson (ed.), From Sabbath to Lord's Day: A Biblical, Historical and Theological Investigation. Grand Rapids, MI.: Zondervan. 311-341.

-. 2010. Bible and Ecology. Rediscovering the Community of Creation. Texas: Baylor University Press.

Brueggemann, W. 1982. Genesis. A commentary in the Interpretation series. Atlanta: John Knox Press.

-. 2014. Sabbath as resistance. Saying no in a culture of now. Louisville: Westminster John Knox.

Buitendag, J. 2019. Die Klub van Rome (“Club of Rome”) se soeke na planetariese welsyn beskou deur die oë van 'n Gereformeerde teoloog. Litnet Akademies, 16, no. 3.

—. 2019. Jy moet die aarde liefhê soos jouself. Litnet Akademies, 16, no. 3.

Charles, R.H. 1913. The Apocrypha and Pseudepigrapha of the Old Testament. Oxford: Clarendon Press.

Cole, H.R. 2003. The Sabbath and Genesis 2:1-3. Andrews University Seminary Studies, 41, no. 1: 5-12.

Collinson, P. 1964. The beginnings of English Sabbataranism. Studies in Church History, 1:207-221.

De Jonge, H.-J. 2016. The Origins of the Sunday Eucharist. Ephemerides Theologicae Lovanienses 92, no. 4: 549-579.

De Lacey, D.R. 1982. "The Sabbath / Sunday question and the law in the Pauline corpus," in D.A. Carson (ed.), From Sabbath to the Lord's day. A biblical, historical and theological investigation. Eugene, OR.: Wipf and Stock, 21-42.

Dieleman, K.J. 2019. The battle for the Sabbath in the Dutch Reformation. Devotion or Desecration? Gottingen: Vandenhoeck \& Rubrecht.

Dressier, H. 1982. The Sabbath in the Old Testament, in D.A. Carson (ed.), From Sabbath to the Lord's day. A biblical, historical and theological investigation. Eugene, OR.: Wipf and Stock, 157-195. 
Fonrobert, C. 205. The political symbolism of the Eruv. Jewish Social Studies, 11(3):9-35.

Fleischacker, S. 2017. “The Jewish Sabbath as a Spiritual Practice," in David McPherson (ed.), Spirituality and the Good Life: Philosophical Approaches. Cambridge: Cambridge University Press, 101-116.

Gribetz, S.K. 2019. "Shabbat with food: From Biblical prohibitions to Rabbinic feasts." [Online]. Available: Thetorah.com/article/Shabbatwith-food-from-biblical-prohibitions-to-rabbinic-feasts.

Herschel, A.J. 1951. The Sabbath. Its meaning for modern man. New York: Farrar, Straus and Giroux.

Holmberg, B. 1998. "Jewish 'versus' Christian Identity in the Early Church.” Revue Biblique, 105, no. 3:397-425.

Jewett, P.K. 1971. The Lord's Day. Grand Rapids, MI: Eerdmans.

Kaiser, D. 2013. "He Spake and it was Done": Luther's Creation Theology in his 1535 lectures on Genesis 1:1-2:4. Journal of the Adventist Theological Society, 24, no. 2:116-136.

Katz, D.S. 1988. Sabbath and sectarianism in Seventeenth Century England. Leiden: Brill.

Kessler, V. 2012. The Sabbath as a remedy for human restlessness. In die Skriflig, 46, no. 2:1-8

Lee, K.E. 2014. "Pre-Puritan Sabbatarians? Henry Billinger on the Sabbath.” [Online]. Available: https://founders.org/2014/05/13/prepuritan-sabbatarins-henry-bullinger-on-the-sabbath-part-2/

Marchinkowski, G. and P.G.R. de Villiers, 2020. The rediscovery of spiritual practices within Protestantism. STJ, 6, no. 1:429-56.

Marks, L.D., T.G. Hatch and D.C. Dollahite 2017. "Sacred practices and family processes in a Jewish context: Shabbat as the weekly family ritual par excellence." Family Process, 57, no. 2:1-13.

McIver, R.K. 2015. "When, Where, and Why did the Change from Sabbath to Sunday Worship take place in the early Church?” Andrews University Seminary Studies, 53, no. 1:15-35. 
Moltmann, J. 1993. "God in Creation. An ecological doctrine of Creation." The Gifford Lectures 1984-1985. Minneapolis: Augsburg Fortress Press.

Nondealers, S. 2013. Reflecting on the Sabbath: Responsibility to act ecologically. M.Th. thesis. Catholic University of Louvain. Faculty of Theology and Religious Studies.

Northeim, B.E.H. 2014. Practicing baptism. Christian practices and the presence of Christ. Eugene: Pickwick.

Olson, D.T. 2008. "Sacred Time: The Sabbath and Christian Worship," in C.M. Bechtel (ed.), Touching the altar. Grand Rapids, MI: Eerdmans.

Orr, R. s.a. "Old Testament Laws: From Sunday to Sabbath: The Puritan Origins of Modern Seventh-day Sabbatarianism," in Grace Communion International. [Online]. Available: https://archive.gci. org/articles/from-sunday-to-sabbath-the-puritan-origins-of-modernseventh-day-sabbatarianism/

Pacner, S. 2013. "The Shabbat as a Sign of Freedom.” Studia Theologica, 51, no. 1:1-23.

Parker, K.L. 1984. "Thomas Rogers and the English Sabbath: the case for a reappraisal." Church History, 53, no. 3:332-347.

Paul II, J. 1998. Dies domini. Encyclical letter on keeping the Lord's day holy. May 31.

Reynaud D. 2016. "Understanding history: Seventh-day Adventists and their perspectives." Teach 10, no. 1:54-62.

Robinson, G. 1988. The origin and development of the Old Testament Sabbath: a comprehensive exegetical approach. Beiträge zur biblischen Exegese und Theologie. Frankfurt am Main; New York: P. Lang.

Rowland, C. 1982. A summary of Sabbath observance in Judaism at the beginning of the Christian era, in D.A. Carson (ed.), From Sabbath to the Lord's day. A biblical, historical and theological investigation. Eugene, OR.: Wipf and Stock, 43-57. 
Smith-Gabai, H. and F. Ludwig. 2011. "Observing the Jewish Sabbath:

A meaningful restorative ritual for modern times." Journal of Occupational Science, 18, no. 4:347-355.

Sokupa, M.M. 2015. "Documented memories of Richard Moko's life and contribution: A Seventh-day Adventist Heritage reflection." SHE, 41, no. 3:171-83.

Sturcke, H. 2005. Encountering the Rest of God: How Jesus Came to Personify the Sabbath. Zürich: TVZ. 17-32.

Veldt, S. 2007. Mark, Christian Attitudes toward the Jews in the Earliest Centuries A.D. Dissertations. 925. [Online]. Available: https:// scholarworks.wmich.edu/dissertations/925.

Vervenne, M. 1996. "Current tendencies and developments in the study of the Book of Exodus," in M. Vervenne, (ed.), Studies in the Book of Exodus: redaction - reception - interpretation. Leuven: Peeters. 245-264.

Volf, M. 2002. " "Theology for a way of life," in D.C. Bass \& M. Volf, Practicing Theology. Beliefs and Practices in Christian Life. Grand Rapids: Eerdmans.

Vorster, J.M. 2005. Ecocide, the integrity of creation and the rights of the next generation. Verbum et Ecclesia 26(3), 867-90.

-. 2011. "Go out and gather each day ...": implications of the ethics of Exodus 16 for modern consumerism. Koers, 76(1)2011:171-192.

Waaijman, K. 2002. Spirituality. Forms, Foundations, Methods. Leuven: Peeters. 869-945.

Weeks, L.B. 1981. “The Scriptures and Sabbath Observance in the South.” Journal of Presbyterian History, 59, no. 2:267-284. 